Article

\title{
Sustainable Well-Being Challenge: A Student-Centered Pedagogical Tool Linking Human Well-Being to Ecological Flourishing
}

\author{
Christine Vatovec $1, *\left(\mathbb{D}\right.$ and Haley Ferrer ${ }^{2}$ (D) \\ 1 Aiken Center, Rubenstein School of Environment \& Natural Resources, and Gund Institute for Environment, \\ Larner College of Medicine, University of Vermont, 81 Carrigan Drive, Burlington, VT 05405, USA \\ 2 Aiken Center, Rubenstein School of Environment \& Natural Resources, University of Vermont, \\ 81 Carrigan Drive, Burlington, VT 05405, USA; Haley.Ferrer@uvm.edu \\ * Correspondence: cvatovec@uvm.edu
}

Received: 12 October 2019; Accepted: 5 December 2019; Published: 15 December 2019

\begin{abstract}
Human behavioral change is necessary if we wish to evolve into a more sustainable human society, but change is hard, especially given that many people equate environmentalism with personal sacrifice. This paper highlights a semester-long assignment in which undergraduate students examined five behaviors that claim to increase happiness with minimal ecological footprints. We used mixed methods to analyze students' self-reported positive and negative affect scores before and after completing each of the five activities, along with descriptions of the carbon footprint of each activity and student self-reflections on whether each challenge promoted "sustainability". Results indicated that students' positive affect increased with each activity, while negative affect decreased. Student reflections indicated that engagement with systems thinking can be used to examine the relationship between their own well-being and the ecological outcomes of each of their chosen activities, as well as alternatives that would decrease their footprint. In final reflections, $85 \%$ of students stated that they would promote these five behaviors among the general public to enhance sustainability efforts. We discuss using the Sustainable Well-being Challenge as a tool to promote behaviors that support both human and ecological well-being.
\end{abstract}

Keywords: sustainability education; higher education; human behavior; carbon footprint; mixed methods

\section{Introduction}

In order to bring human consumption of natural resources within planetary boundaries, there is a critical need to shift human behaviors away from current exploitative practices [1,2]. Present cumulative global consumption rates would require the equivalent biocapacity of 1.6 Earths [3]. Recent analysis of consumption across 43 countries suggests that household consumption is responsible for $65 \%$ of global carbon emissions, $81 \%$ of water use, $70 \%$ of land use, and $51 \%$ of material resource use [4]. Of course, consumption varies dramatically between wealthy and impoverished nations, and current evidence shows that consumption rates in low-income countries would be able to support 13.6 billion people if practiced on a global scale, while that of high-income countries could only sustain 2.1 billion people-merely one fifth of the current world population [5]. A change in the household consumption behaviors of high-income countries could lead to a drastic decrease in the cumulative human ecological footprint.

However, changing consumption behaviors is a complicated matter. Keeping up with the Joneses on the treadmill of consumption is a means by which people show their status and understand their value within society [6]. Likewise, modern consumption provides convenience-driving 
a single-occupancy vehicle to the grocery store to pick up processed foods in tidy packaging can be seen as much easier and less time-consuming than more hands-on ways of preparing a meal. As a result, environmentally-preferred behaviors can often be seen as inconvenient sacrifices at a minimum $[7,8]$, or requiring drastic and unfavorable lifestyle changes at a maximum [7]. However, many researchers who study relationships between the environment and human well-being suggest that it is quite possible to be "environmentally friendly" while also improving personal affect and happiness $[9,10]$.

The concept of sustainable well-being refers to individual and organizational pursuits that contribute to human happiness as well as environmental sustainability $[9,11]$. Such a term holds great powers and implications for the future of the environment as well as the human species, as it creates a foundation for modern lifestyles in which environmental and human flourishing can be achieved simultaneously. Several human progress indicators have been developed to provide metrics showing that human well-being and ecological health can coexist, including the Genuine Progress Indicator, Index of Sustainable Economic Welfare, and the Well-being and Progress Index [12,13]. Through these indices and related studies of human well-being, we find numerous non-consumptive behaviors that elevate the human experience without taxing the natural environment $[7,14,15]$. Nic Marks, a statistician who helped develop the Happy Planet Index, studies the role of happiness in sustainability and has concluded that the most impactful indicators of human happiness do not involve behaviors which degrade the environment or increase ecological footprints [16]. Building upon the groundbreaking work of Richard Easterlin, which demonstrated that rising per-capita income is not associated with a rise in happiness levels [17], Marks criticizes the cultural importance of consumption, arguing that although GDP has been adopted as the key measure for national success, the metric was never envisioned to be used as an indicator of human welfare. Marks suggests that human well-being cannot be enhanced through income, GDP, and related consumption; rather, happiness can be promoted through five evidence-based behaviors: forming social connections, being physically active, taking notice or being mindful of the world, participating in lifelong learning, and giving as a form of helping others [18]. Marks claims that all of these actions can easily be accomplished without extracting resources, emitting carbon, or otherwise contributing to environmental degradation. Unlike wealth and income, these five indicators of happiness are able to be equally accessed and carried out by all populations, regardless of geographical location or demographic circumstances. Marks suggests that by promoting these behaviors, it is quite possible to achieve heightened levels of human and environmental well-being on a global scale [16].

Higher education has a role to play in such behavioral change, both by modeling sustainable well-being through institutional practices and through research and teaching that engage tomorrow's leaders with a positive conception of sustainable consumption [19]. Competency-based learning, which integrates students' knowledge, skills, and attitudes, has been offered as one higher education approach to transformative behavior change [20], with coursework that offers cross-disciplinary learning viewed as particularly beneficial [21]. The course Human Health $\mathcal{E}$ the Environment at the University of Vermont (UVM) is one of several courses designed to meet the campus Sustainability General Education requirement through a focus on sustainability competencies [22]. Moreover, this course encourages students to participate in active learning [23], defined by Allen and Turner as "seeking new information, organizing it in a way that is meaningful, and having the chance to explain it to others" [24].

The purpose of this paper is to highlight a semester-long assignment in UVM's Human Health $\mathcal{E}$ the Environment course, in which undergraduate students were required to examine the five evidence-based behaviors that Marks claims increase happiness without suffering a large ecological footprint: physical activity, social connection, mindfulness, lifelong learning, and helping others. Using a lens of positive psychology [25], particularly with regard to providing students with authentic hope for the future [26], we sought to determine whether students would discover positive aspects of human behavior that can lead to both human and ecological well-being through this "Sustainable Well-Being Challenge" (SWBC). We provide results from quantitative psychosocial survey data reported by the students (the validated Positive and Negative Affect Schedule (PANAS) survey), as well as qualitative data 
from students' written reflections. We provide the SWBC as a pedagogical tool to be used for teaching sustainability at undergraduate level, and we recommend that instructors situate the SWBC within the context of their own courses to best meet the needs of their students.

\section{Materials and Methods}

\subsection{Course Context}

UVM's Human Health $\mathcal{E}$ the Environment course is an introductory 100-level environmental health course, which has enrolled between 30 and 60 students for at least one semester each year since fall 2014 . The course begins by situating "health" within a context of sustainability. After working collectively to define the term "health", we use the "sustainability buffet" teaching tool [27] as a starting place for students to grapple with the complexity of defining the term sustainability so that they may develop, reflect upon, and revise their own personal definitions of the term. Within this context, the lead author shares the evolution of her own current definition of sustainability with the class:

$$
\text { Sustainability }=\infty \text { human flourishing }+ \text { ecological flourishing. }
$$

In this formula, human flourishing includes health and happiness that are equally accessible to all people, both individually and in relationships, in local communities and global society; while ecological flourishing includes resilient and stable global biotic and abiotic systems. From this starting point of discussing health in a context of sustainability, we watch Nic Marks' TED Talk The Happy Planet Index, [16] then posit the question of whether it is possible to engage in behaviors that enhance human well-being (health and happiness) without, as Marks suggests, "costing the planet".

\subsection{Sustainable Well-Being Challenge}

After discussing The Happy Planet Index, students are introduced to the semester-long SWBC series of six assignments (see Supplemental Material). The first five assignments are due every other week over the course of the semester and require students to (1) self-select an activity related to the week's SWBC topic (week 2-social connection, week 4-mindfulness, week 6-lifelong learning, week 8-helping others, week 10-physical activity), (2) complete the validated Positive and Negative Affect Schedule (PANAS) [28] immediately before and after completing their activity, and (3) write a reflection on their activity, PANAS results, all materials used that have a carbon footprint, and a summary of whether or not their activity supports Nic Marks' claim that the behavior improves well-being without "costing the planet". In class, students discuss their findings and compare and contrast outcomes of each activity (i.e., carbon footprint of activities and psychological well-being in relation to carbon footprint). The sixth and final assignment requires students to complete a final reflection comparing all five activities and discuss whether or not the student would promote these behaviors as tools to enhance human well-being with minimal ecological footprint [29].

\subsection{Data Analysis}

We analyzed the SWBC assignments from 35 students who completed the Human Health $\mathcal{E}$ the Environment course during the 2017 fall semester. We used Microsoft Excel (2013) to calculate descriptive statistics and average pre- to post-activity change for PANAS surveys. Qualitative data from student reflections were coded and analyzed using directed content analysis [30] in NVivo 12 Pro (2019).

This study was deemed exempt by the University of Vermont Institutional Review Board (Study 00000187).

\section{Results and Discussion}

Our results indicate that (1) the majority of students experienced personal benefit from increased positive affect and decreased negative affect after completing each of the five challenge activities, 
(2) written statements indicate critical reflection and transformative learning among students, and (3) the majority of students would recommend promoting these activities as ways to support both human and ecological well-being.

\subsection{Effect of Activities on Positive and Negative Affect}

Measuring affect provides insight into a person's mood, which is an indication of psychological well-being. Positive affect is defined as "the extent to which a person feels enthusiastic, active, and alert," with high positive affect indicating "a state of high energy, full concentration, and pleasurable engagement, whereas low [positive affect] is characterized by sadness and lethargy" [28]. In contrast, negative affect is characterized by adverse mood states, with a high measure indicating "anger, contempt, disgust, guilt, fear, and nervousness, with low negative affect being a state of calmness and serenity." Our results indicate students' positive affect increased with each of the five SWBC activities, while negative affect decreased (Table 1). Physical activity had the greatest increase in positive affect $(+15)$, followed by helping others $(+12)$, lifelong learning and social connection (both +9$)$, and mindfulness $(+8)$. Mindfulness had the greatest decrease in negative affect $(-10)$, followed by physical activity and helping others (both -8$)$, lifelong learning (-7), and social connection (-6).

Table 1. Effect of Sustainable Well-Being Challenge activities on positive and negative affect among students $(n=35)$.

\begin{tabular}{ccccccc}
\hline & N 1 & \multicolumn{3}{c}{ Positive Affect } & \multicolumn{2}{c}{ Negative Affect } \\
\cline { 3 - 7 } & $\begin{array}{c}\text { Mean Change } \\
\text { Pre- to } \\
\text { Post-Activity }\end{array}$ & $\begin{array}{c}\text { Std. } \\
\text { Deviation }\end{array}$ & $\begin{array}{c}\text { Std. } \\
\text { Error-Mean }\end{array}$ & $\begin{array}{c}\text { Mean Change } \\
\text { Pre- to } \\
\text { Post-Activity }\end{array}$ & $\begin{array}{c}\text { Std. } \\
\text { Deviation }\end{array}$ & $\begin{array}{c}\text { Std. Error } \\
\text { Mean }\end{array}$ \\
\hline Social connection & 28 & +8.5 & 12.712 & 2.402 & -5.8 & 7.107 \\
Mindfulness & 30 & +8.3 & 11.110 & 2.028 & -10.3 & 8.726 \\
Lifelong learning & 31 & +9.2 & 8.948 & 1.607 & -6.5 & 7.534 \\
Helping others & 35 & +11.7 & 9.262 & 1.566 & -8.0 & 1.593 \\
Physical activity & 32 & +15.4 & 8.477 & 1.499 & -7.7 & 5.878 \\
\hline
\end{tabular}

${ }^{1}$ Only complete assignments were included in data analysis, causing sample size to vary.

\subsection{Critical Reflection and Transformational Learning for Sustainability}

Systems thinking is increasingly used in the college classroom to help students grasp the complexity of interconnections in the world, particularly in relation to sustainability [31]. The interpretive approach to environmental sustainability using systems theory offers a pedagogical approach that we find useful for examining student learning in relation to real-world behaviors [32]. In particular, the interpretive approach suggests that students move through the processes of awareness, appreciation, and ethical action when interpreting and constructing knowledge. Our analysis of students' written reflections suggests that the SWBC afforded them with opportunities to conceptualize sustainability through the effects of human actions on social and ecological processes. The following quotations from student reflections provide evidence of deep engagement with systems thinking as it relates to personal action:

I found this activity compelling because I was able to think a lot about how specific external factors (social and environmental) interact with my patterns and moods. One of the things I thought about, as well, was the fact that a discussion of privilege is necessary in globalizing this sort of approach. I am lucky to have a car in order to travel to my friends, lucky to be able to afford to take a night off, lucky to have access to a safe outdoor space! (Social connection reflection \#4)

It is crucial to consider the fundamental input of any activity/product, no matter how negligible it may seem: the myriad industrial processes that turned sheep's wool into a consumer good on the store shelf, the fossil fuels that built and maintain the roads I drove on, the resource and energy intensity that goes into powering Michael's craft store where 
I purchased the materials, my living room where I learned the craft, the factories that manufactured the clothing on my back and furniture beneath me, so on and so forth. (Lifelong learning reflection \#10)

Furthermore, student reflections support the idea that transformational learning, in which critical reflection allows a learner to revise their assumptions and understanding of experiences, can function in support of sustainability education [33-35]. Here, we see that SWBC activities supported students' understanding of how human well-being can be attained through critical reflection of alternative actions that can improve happiness without reliance upon environmentally damaging materials:

There is no real reason to have to consume or use resource demanding items or emit carbon into the air in order to increase ones well being. There are many ways to go about that challenge while also having a very small carbon foot print. (Mindfulness reflection \#3)

In this age of global climate change, it is crucial to consider our daily activities and their carbon footprints, and even though our activity did cost the planet in a significant way, at least I have the skills and worldview to be conscious of my actions, think critically about my actions, and do better in the future. (Helping others \#11)

Such learning allows for the transformational thinking that offers a foundation for future action and behavioral change in support of sustainability goals:

It is certainly a challenge shifting one's lifestyle from one way to another, especially being accustomed to being sort of mindless when it comes to being a consumer, but it is a new approach that I am happy to partake in. (Physical activity reflection \#4)

Completing this suite of activities offered multiple refreshing reminders that I can indeed step outside the comfort of my usual routines and ways of living and emerge fulfilled, encouraged and overall more whole of a person. (Final reflection \#9)

In final reflections, $85 \%$ of students stated that they would promote all five of these behaviors among the general public to enhance sustainability efforts (Table 2). For example, one student noted:

I do believe that all of these activities should be promoted, in order to help create a sustainable future. The most important and influential aspect about these activities that I have observed, is the fact that they all help cultivate a environmentally cognizant mindset. While some individuals will probably find some activities more effective than others, I think that the combination of all five helps to achieve a holistic understanding of sustainability. Having the mentality that sustainability is something that one can strive for in all aspects of life is crucial in fostering the idea of a flourishing future. (Final reflection \#26)

Table 2. Student reflections on whether they would promote each of five tested behaviors to enhance sustainability efforts among the general public $(n=26)$.

\begin{tabular}{ccc}
\hline Activity & $\mathbf{n}^{\mathbf{1}}$ & $\mathbf{\%}$ \\
\hline Physical activity & 23 & 88 \\
Mindfulness & 23 & 88 \\
Social connection & 23 & 88 \\
Helping others & 22 & 85 \\
Lifelong learning & 22 & 85 \\
ALL five behaviors & 22 & 85 \\
\hline assignments were included in data analysis, causing sample size to vary.
\end{tabular}

${ }^{1}$ Only complete assignments were included in data analysis, causing sample size to vary. 


\subsection{Limitations, Recommendations, and Further Research}

Our analysis was limited by three key factors: (1) the SWBC relies on student self-selection of activities such that each activity differed in scope, effort, and time commitment and as such were not directly comparable, (2) the SWBC relies on student self-reporting, so we must assume that all information (especially PANAS scores) was provided accurately and in good faith, and (3) we did not collect demographic data so we cannot determine whether all SWBC activities benefited all students equally, and whether some populations are more likely to benefit than others. We recommend that educators revise the SWBC to best suit the needs of their unique learning environment, paying particular attention to cases where students identify activities that do not support Nic Marks' claim that these five behaviors promote human well-being without a large carbon footprint - those insights may indeed provide the best opportunity for expanding conceptual understanding. As one student reported:

Ultimately, everything we do has an impact on the environment in some way. Because of this, I do not support Nic Marks' statement that well-being [can] be increased without "costing the planet." The idea that we cannot be social without having an impact on the environment is most likely why my positive PANAS score decreased and my negative PANAS score increased. However, we can become more efficient with our resources so that we have a lesser impact on the environment.

(Social connection reflection \#13)

\section{Conclusions}

Our aim has been to provide a pedagogical tool that may prove useful for transformative learning in higher education in order to promote social change toward more sustainable behaviors. Our findings show that students who completed the SWBC reported a mean increase in positive affect ranging from 8.3 to 15.4 points on the PANAS scale, depending on the activity, and a mean decrease in negative affect ranging from -5.8 to -10.3 points. Furthermore, students' written reflections on the SWBC assignments show critical engagement with the relationship between PANAS outcomes and the carbon footprint of selected activities, indicating that participants were able to identify the relationship between their own well-being and the ecological sustainability of each activity. Finally, 85\% of students reported that they would recommend that the general public engage with all five of these behaviors in efforts to promote human well-being while limiting consumptive practices.

We invite the reader to adapt the SWBC tool to their teaching and learning context, test its effectiveness in promoting a positive view of environmentally-preferred behaviors that enhance human well-being, and evolve this teaching approach so that it becomes a more useful agent of social change in support of a more sustainable future in which both humans and our ecological communities may flourish.

Supplementary Materials: The following are available online at http://www.mdpi.com/2071-1050/11/24/7178/s1, Sustainable Well-Being Assignments, and SWBC Dataset.

Author Contributions: C.V. was the instructor of record for the course Human Health $\mathcal{E}$ the Environment and primary investigator of this study, and directed the conceptualization, methodology, formal analysis, writing-Original draft preparation, review and editing, and project administration of this work. H.F. assisted with formal analysis, and writing-Original draft preparation, review and editing.

Funding: This research received no external funding.

Acknowledgments: The authors wish to thank the students of the Human Health $\mathcal{E}$ the Environment course for their engagement and participation in the Sustainable Well-Being challenge. In addition, the authors wish to thank University of Vermont Office of the Provost and Senior Vice President Professional Development Fund and the Rubenstein School of Environment and Natural Resources for providing funding of Open Access expenses.

Conflicts of Interest: The authors declare no conflict of interest. 


\section{References}

1. Rockström, J.; Steffen, W.L.; Noone, K.; Persson, Å.; Chapin, F.S., III; Lambin, E.; Lenton, T.M.; Scheffer, M.; Folke, C.; Schellnhuber, H.J.; et al. Planetary boundaries: Exploring the safe operating space for humanity. Ecol. Soc. 2009, 14, 32. [CrossRef]

2. Steffen, W.; Richardson, K.; Rockström, J.; Cornell, S.E.; Fetzer, I.; Bennett, E.M.; Biggs, R.; Carpenter, S.R.; De Vries, W.; De Wit, C.A.; et al. Planetary boundaries: Guiding human development on a changing planet. Science 2015, 347. [CrossRef] [PubMed]

3. Fund, W.W. Living Planet: Report 2016: Risk and Resilience in a New Era; World Wide Fund for Nature: Gland, Switzerland, October 2016.

4. Ivanova, D.; Stadler, K.; Steen-Olsen, K.; Wood, R.; Vita, G.; Tukker, A.; Hertwich, E.G. Environmental impact assessment of household consumption. J. Ind. Ecol. 2016, 2, 526-536. [CrossRef]

5. Assadourian, E. Transforming cultures: From consumerism to sustainability. J. Macromarketing 2010, 30, 186-191. [CrossRef]

6. Bell, M.M.; Bell, M. An Invitation to Environmental Sociology; Pine Forge Press: Thousand Oaks, CA, USA, July 2011.

7. Brown, K.W.; Kasser, T. Are psychological and ecological well-being compatible? The role of values, mindfulness, and lifestyle. Soc. Indic. Res. 2005, 74, 349-368. [CrossRef]

8. Litfin, K. The sacred and the profane in the ecological politics of sacrifice. Environ. Politics Sacrif. 2010, 117-143. [CrossRef]

9. O'brien, C. Sustainable happiness: How happiness studies can contribute to a more sustainable future. Can. Psychol. 2008, 49, 289. [CrossRef]

10. Fischer, D.; Stanszus, L.; Geiger, S.; Grossman, P.; Schrader, U. Mindfulness and sustainable consumption: A systematic literature review of research approaches and findings. J. Clean. Prod. 2017, 162, 544-558. [CrossRef]

11. Di Fabio, A. The psychology of sustainability and sustainable development for well-being in organizations. Front. Psychol. 2017, 8, 1534. [CrossRef]

12. D'Acci, L. Measuring well-being and progress. Soc. Indic. Res. 2011, 104, 47-65. [CrossRef]

13. Lawn, P.A. A theoretical foundation to support the Index of Sustainable Economic Welfare (ISEW), Genuine Progress Indicator (GPI), and other related indexes. Ecol. Econ. 2003, 44, 105-118. [CrossRef]

14. Kasser, T. Psychological need satisfaction, personal well-being, and ecological sustainability. Ecopsychology 2009, 1, 175-180. [CrossRef]

15. Jacob, J.; Jovic, E.; Brinkerhoff, M.B. Personal and planetary well-being: Mindfulness meditation, pro-environmental behavior and personal quality of life in a survey from the social justice and ecological sustainability movement. Soc. Indic. Res. 2009, 93, 275-294. [CrossRef]

16. Marks, N. The Happy Planet Index. In TEDGlobal; TED, Ed.; TED: Oxford, UK, 2010.

17. Easterlin, R.A. Does economic growth improve the human lot? Some empirical evidence. In Nations and Households in Economic Growth; Elsevier: New York, NY, USA, 1974; pp. 89-125.

18. Marks, N. The Happiness Manifesto: How Nations and People Can Nurture Well-Being; TED books: New York, NY, USA, 2011.

19. Göran, F.; Julie, N.; Leendert, A.V. Sustainable Development and Higher Education: Acting with a Purpose. Sustainability 2019, 11, 3831. [CrossRef]

20. Dlouhá, J.; Heras, R.; Mulà, I.; Salgado, F.P.; Henderson, L. Competences to Address SDGs in Higher Education-A Reflection on the Equilibrium between Systemic and Personal Approaches to Achieve Transformative Action. Sustainability 2019, 11, 3664. [CrossRef]

21. Walter, L.F.; Kay, E.-P.; Petra, M.-H.; Mark, M.; Leendert, V.; Ulisses Miranda, A.; Paula, B.-N.; de Sousa, L.O.; Paula, C.; Ali, B.; et al. Implementing Innovation on Environmental Sustainability at Universities Around the World. Sustainability 2019, 11, 3807. [CrossRef]

22. Hill, L.M.; Wang, D. Integrating sustainability learning outcomes into a university curriculum: A case study of institutional dynamics. Int. J. Sustain. High. Educ. 2018, 19, 699-720. [CrossRef]

23. Chickering, A.W.; Gamson, Z.F. Seven principles for good practice in undergraduate education. Aahe Bull. 1987, 3, 7 . 
24. Allen, D.; Tanner, K. Infusing active learning into the large-enrollment biology class: Seven strategies, from the simple to complex. Cell Biol. Educ. 2005, 4, 262-268. [CrossRef]

25. Seligman, M.E.; Csikszentmihalyi, M. Positive psychology: An introduction. In Flow and the Foundations of Positive Psychology; Csikszentmihalyi, M., Ed.; Springer: New York, NY, USA, 2014; pp. 279-298.

26. Langmaid, K.F. Discovering Authentic Hope: Helping Students Reflect on Learning and Living with Purpose. In Learner-Centered Teaching Activities for Environmental and Sustainability Studies; Byrne, L.B., Ed.; Springer: New York, NY, USA, 2016; pp. 73-78.

27. Natkin, L.W.; Kolbe, T. Enhancing sustainability curricula through faculty learning communities. Int. J. Sustain. High. Educ. 2016, 17, 540-558. [CrossRef]

28. Watson, D.; Clark, L.A.; Tellegen, A. Development and validation of brief measures of positive and negative affect: The PANAS scales. J. Personal. Soc. Psychol. 1988, 54, 1063. [CrossRef]

29. Rees, W.; Wackernagel, M.; Testemale, P. Our Ecological Footprint: Reducing Human Impact on the Earth; New Society Publishers: Gabriola Island, BC, Canada, 1996.

30. Hsieh, H.F.; Shannon, S.E. Three approaches to qualitative content analysis. Qual. Health Res. 2005, 15, 1277-1288. [CrossRef] [PubMed]

31. Arnold, R.D.; Wade, J.P. A definition of systems thinking: A systems approach. Procedia Comput. Sci. 2015, 44, 669-678. [CrossRef]

32. Porter, T.; Córdoba, J. Three views of systems theories and their implications for sustainability education. J. Manag. Educ. 2009, 33, 323-347. [CrossRef]

33. Moore, J. Is higher education ready for transformative learning? A question explored in the study of sustainability. J. Transform. Educ. 2005, 3, 76-91. [CrossRef]

34. Ball, G.D. Building a sustainable future through transformation. Futures 1999, 31, 251-270. [CrossRef]

35. Cranton, P. Understanding and Promoting Transformative Learning: A Guide to Theory and Practice; Stylus Publishing, LLC: Sterling, VA, USA, 2016.

(C) 2019 by the authors. Licensee MDPI, Basel, Switzerland. This article is an open access article distributed under the terms and conditions of the Creative Commons Attribution (CC BY) license (http://creativecommons.org/licenses/by/4.0/). 